\title{
WHEN HARRY MET ZUCKERMAN: SELF-REFLEXIVITY AND METAFICTION IN PHILIP ROTH AND WOODY ALLEN
}

Tomás Creus

Universidade Federal do Rio Grande do Sul

\section{Abstract}

The objective of this essay is to compare the works of novelist Philip Roth and film-maker Woody Allen in what regards their treatment of the highly complex theme of the interrelations between fiction and reality. A comparative analysis of selected Roth's novels and Allen's films evinces their recurrent preoccupation with the creation of art and its implications, be it through the choice of writers or artists as main characters, be it through plots that mix real facts with invented ones and imaginary characters with real ones, be it through the use of autobiographical elements in a fictional discourse-all metafictional devices that call attention to the artist's own process of creation.

Keywords: film; literature; fiction.

Writer Philip Roth and film-maker Woody Allen share a curiously similar background. Both have about the same age, both are JewishAmerican (and both have been eventually criticized by orthodox Jews), both live or have lived for a long time in New York. It is not so strange, 
then, given that they share a similar cutural and social background, that they approach similar themes, including adultery (i.e. Allen's Hannah and Her Sisters, Roth's Deception), psychoanalysis (i.e. Allen's Another Woman, Roth's Portnoy's Complaint), death (i.e. Allen's Crimes and Misdemeanors, Roth's Sabbath's Theater), or, of course, Judaism (i.e. Allen's Deconstructing Harry, Roth's Operation Shylock), usually treating such themes with a good deal of humor. More peculiar is that both authors have also extensively pondered in their work on the role of the artist in society and the relation between life and art.

It is not very clear whether Allen likes Roth's work or vice-versa, but it is certain that they know each other's work to some extent. In Roth's novel Operation Shylock, a character makes a not-altogether complimentary mention of Woody Allen. In The Kugelmass Episode, an early short story by Woody Allen which would later become the blueprint for his film The Purple Rose of Cairo, the main character mentions Portnoy's Complaint. Regardless of their personal differences, this essay aims at a comparative reading of both artists' work concerning the particular theme of the interrelations between life and art.

\section{Real and fictional characters}

One of the earliest and most common devices of metafiction, that is, a fictional narrative that somehow comments on its own process of creation, is the superposition of two narrational levels. In one level, we read the story as an account of fictional events that happen to a character or a group of characters; on another level, however, the author might choose to make us aware of the fictional status of the selfsame story, calling our attention to its own structure. Although it has been used extensively by so-called "postmodern" authors such as Jorge Luis Borges, Italo Calvino or Thomas Pynchon, it is not a new device. It was used, for example, in Don Quixote, when the Knight and Sancho hear about a book being written about them, which narrates the same adventures that we are currently reading; in Hamlet, where a playwithin-the-play repeats the central argument; in Pirandello's Six 
Characters in Search of an Author, where the characters literally become conscious of their fictional status.

Woody Allen uses the device of mixing "real" and "fictional" characters, exploring the connections between the artist and his work and between fiction and reality in several films, to the point that it might be considered as one of his major themes. This, apparently, goes back to his childhood, when he used to go to the cinema to escape daily life:

One of the pleasures of going into a movie house is to avoid the harsh realities of life (...) I lived in Brooklin, and on these hot, hazy summer days when it was humid and you couldn't move and nobody had anything to do, there were thousands of movie houses around, and you could walk in for 25 cents. (...) It was just a total, total joy. The greatest kind of tranquilizer and embalmment that you could think of (Woody Allen on Woody Allen, 149).

In a few films this theme of a dreary reality as opposed to a beautiful fantasy is shown as a direct interaction between fictional entities (mainly from the cinema) and the other characters. One of such instances was the stage play Play it Again, Sam. It was adapted for the movies in the seventies, with a screenplay penned by Allen himself (the director was Herbert Ross). In this film we have a movie character-Bogey, the Humprey Bogart tough persona from Casablanca and a few noir films -who interacts with a supposedly real character, Alan Felix, a fan of Casablanca, played by Woody Allen. This fictional movie character interacts only with the protagonist, and it could be considered as a sort of "personified conscience", since the other characters cannot see him: it's all in Felix's mind, we could say. In the film, Felix, a fan of Casablanca, has difficulties in relationships with women, and tries to solve his problems by listening to Bogart's advice. The main question of the film is whether fiction can be used for a model for the so-called "real life", and the final answer seems to be negative, since the character played 
by Allen only manages to attain his objective when he stops imitating his idol and develops a more personal style.

In The Purple Rose of Cairo (1986), written and directed by Allen, the situation is more complex. Here we also have the intrusion of a fictional character into the realm of the physical world: a character from the movies comes out of the screen, falling in love with a member of the audience. Contrary to what happens in Play It Again, Sam, this does not happen only in the head of the spectator (played by Mia Farrow), but it affects the "real world" as well. Such confusion, of course, causes several conflicts, in Cecilia's life and in those of everyone else in the story, including the other film characters who remain inside the screen. While the "real world" is all shot in color as a realistic period piece (representing the thirties), visually the film-within-the-film is lit as a black and white film of the same period. "It was like one of those films I saw as a kid, what I called 'champagne comedies' - those comedies from the 1930s and 1940s with all those romantic people who wore tuxedos and went to big nightclubs and lived in penthouses and drank champagne all the time" (Woody Allen on Woody Allen, 37). When the character leaves the screen, the other characters start to look outside the screen towards the movie audience to an almost magic effect fictional characters talking from a movie screen to other characters who reply, unaware of the fact that they also are trapped inside a movie screen and are being watched by us.

In The Reluctant Film Art of Woody Allen, Peter J. Bailey argues that Allen always shows a certain self-consciousness about the making of art, a sort of teasing self-referentiality never completely absent from his films, be it in the extensive use of quotations or references to films by his idols Fellini and Bergman, be it in his creation (and representation) of characters who are artists, writers or performers. To Bailey, the key to Allen's films lies exactly in his ambivalent view of art and artists, wavering between skepticism in whatever social function art might possess and the attempt to produce artistic films: Allen is a "Modernist filmmaker, whose movies gravitate incessantly -if reluctantly-toward the interrogation of their own conditions of 
postmodernist skeptiscism, disillusionment, and narcissistic selfreflexivity" (Bailey, 5).

Philip Roth is also concerned with the creation of art and its implications, and has used metafictional devices in his work as well. Although his first novels were mostly realist fiction, portraying scenes of Jewish life or middle-class anxiety in works such as Goodbye Columbus (1958) or When She Was Good (1959), and although he never totally abandoned a certain "realistic" view of characters and events, he soon evolved to an extremely self-reflexive style, more concerned with the reproduction of events in literary form than with the events themselves. Although Portnoy's Complaint (1969), a brilliant satire about sex and Jewish stereotypes, is the book that would make him famous, perhaps the real turning point in Roth's career is The Ghost Writer (1979), the first appearance of his alter ego Nathan Zuckerman, a narrator-character who in several ways mirrors Roth himself, and who would appear in several other novels from then on. Being a writer, Zuckerman is naturally concerned with the transformation of reality into fiction. Indeed, perhaps Roth's most ambitious experiment in metafiction is The Counterlife (1987), where several episodes present alternative lives of the main characters, including Nathan Zuckerman, and which ends with the letter of a character, Maria, to Zuckerman, acknowledging her own fictional status. It is a novel, indeed, "that undermines its own fictional assumptions" (Roth qtd. in Millbauer and Watson, 11), starting from its episodic and ramificated structure. In the first episode, "Basel", Nathan's brother Henry has to decide whether he tries a risky operation for his heart or not. Pills could solve his cardiac problem, but they have a side-effect: they render him impotent. Consequently he has to choose whether to risk his life in a complicated surgery or live under the medicine, accepting its collateral effect. He chooses to risk the operation - and dies. However, in the second episode, Henry is, surprisingly, still alive. This is, in effect, not a continuation of the story, but an alternate episode-a "counterlife" - in which he chooses not to have the operation. But the surprises do not end there: in yet another episode, Henry finds Nathan's unpublished novels in a 
drawer. One of the drafts is actually the first episode of the book The Counterlife, in which Nathan narrates his brother's fictional death. And so on, in a succession of fiction-within-the-fiction episodes, one coming out of the other like those famous Russian matriochka dolls, only that here we never know for sure which one is inside which, what is "reality" and what is "fiction".

\section{Autobiography as fiction}

Most readers or spectators are used to the mixture of genres and the interpolation of different levels of "fiction" and "reality" that caracterizes much of postmodernist literature and film. Yet there is one kind of mixture which still puzzles at least part of the public: the use of autobiographical events in the construcion of fictional stories. For some reason, many literal-minded readers or spectators still try to isolate from the whole the facts that actually happened in the author's life, perhaps in the attempt to get a glimpse of the writer or film-maker's private life. In the case of Roth,

Throughout his life he has been plagued by readers who believe that his success in giving the appearance of life to what are ultimately just textual constructs is proof that his art is mimetic and that all he has done is to brilliantly reproduce the circumstances of his life in fictional disguise. (Finney, 2)

The truth, of course, is more complex. Nathan Zuckerman and Roth's many other alter-egos such as Alexander Portnoy, Peter Tarnopol and David Kepesh have indeed many similarities or points of contact with Philip Roth's own life and personality. But the author makes clear that those characters are "wrongly interpreted as a veiled autobiography"; they are actually a "kind of idealized architectonic drawing for something that could be built—or that is yet to be built-using the materials that reality itself furnishes" (qtd. in Halio, 126). To Roth, "there is a clear difference between the autobiographic writer that people think 
I am and the autobiographical writer that I am" (qtd. in Halio, 94). Personal life is just another element in the hands of the writer. Everything, even autobiographical material, is fair game to be used in a fictional work: but it needs to be transformed, reshaped to serve the story, thus becoming in the process something completely different.

The crude cliché is that the writer is solving the problem of his life in his books. Not at all. What he's doing is taking something that interests him in life and then solving the problem of the book-which is, How do you write about this? The engagement is with the problem that the book raises, not with the problems you borrow from living. Those aren't solved, they are forgotten in the gigantic problem of finding a way of writing about them. (Roth qtd. in Alvarez, 1)

The confusion that some people make between author and narrator is hard to dissipate, and certainly increases as the author avoids clearcut separations between fact and fiction, so that the reader promptly identifies the author and his private life with the narrator of a particular story and the incidents which happen in it. In Zuckerman Unbound, we learn that the character-narrator Nathan Zuckerman has written a best-seller, Carnovsky, a book accused by some of being pornographic, just as Roth's earlier book Portnoy's Complaint was. In the story, the narrator is approached by several characters who talk to him about the book or call him by the character's name: "They had mistaken impersonation for confession and were calling out to a character who lived in a book" (Zuckerman Unbound, 140). Of course, this is something that might have hapenned to Philip Roth, who became similarly famous after having written Portnoy's Complaint, and was very disturbed by the subsequent celebrity. There are several other incidents in the same book which could be described as having a parallell with Roth's own life, such as his failed marriage, the loss of his father to cancer, among other examples, not counting all the other novels that also seem to allude to Roth's personal life, such as My Life As a 
Man, which some see as an account of his first marriage, or the aptlynamed Deception, in which the main character is called "Philip" and has a relationship with a British woman (the British actress Claire Bloom was his wife at the time). But the superficial similarity of events and characters to parallel events and persons in the author's life is the less relevant aspect of any novel. As Roth says (through the mouth of a character, of course), "Contrary to the general belief, it is the distance between the writer's life and his novel that is the most intriguing aspect of his imagination" (Counterlife, 170).

The same temptation to identify autobiographical elements in a fictional work seems to lead some viewers and critics of Woody Allen. Annie Hall (1979) is considered a breakthrough film for him, or at least the first one in which he started to develop a more clear personal style. And it is also the first film in which some critics and members of the audience started to notice autobiographical elements. Now, the film deliberately uses a confessional tone: it begins with Allen addressing the audience, looking directly into the camera, as if he was a stand-up comedian. The fact, though, is that his audience is sitting in a movie theater. The allusion to comedy is not gratuitous because his character in the film is, indeed, a stand-up comedian, just as Allen himself had been in the beginning of his career. The effect of such beginning, whether intended or not, is that it helps to blur the difference between the character played by Allen and the director-actor, who, after all, in the mind of the audience, is just like the character in the film. Throughout the film, Allen uses this mode of addressing the audience several times, sometimes in the middle of a conventional dramatic sequence. It is not really a novel technique - it had been used before in other films and it derives, basically, from the asides of the theatre, in which the inner thoughts of a character are revealed in such way. But in the cinema, this kind of effect makes us feel closer to the character because in a way we become his confidents: he seems to be talking directly to each spectator.

Other "autobiographical" themes present in the same film are that of growing up in a Jewish family and that of celebrity-since from early on in his film career Allen became well-known and could be 
recognized by people in the street. In a scene from Annie Hall, his character is approached by two apparently menacing elements who turn out to have seen him on a television interview and merely want an autograph. A similar incident might have happened to Woody Allen in real life. One characteristic of film as an art form is that the audience several times mistakes the personal traits of a certain character with those of the actor who plays it. Some actors become much identified with specific characters that they play, and that is very clear in the case of Allen, who, in the line of great screen comedians such as Buster Keaton or Charles Chaplin, is specialized in playing a particular comic character who, although technically not always the same, since his name, profession and general character changes from film to film, is identified by the spectator as always the same (a neurotic, hypochondriac, clumsy, intellectual, urban type-traits which are associated to the "real" Woody as well). Of course, since Woody Allen is usually the writer, director and main actor in his films, the confusion becomes even greater. In Husbands and Wives, for instance, Woody Allen and Mia Farrow play a couple in crisis, mirroring their own tribulations at the time- and if the film eventually became a box office success (for Allen's standards), it was mainly because of spectators who would not normally watch his movies, but who were attracted by the media frenzy over Allen and Farrow's ongoing divorce. As Allen's biographer, Julian Fox, puts it:

His use of names and anedoctes taken from real life to give color to his screenplays has never been denied, even if the real incidents of his experience were imaginatively distorted by the creative process. As he himself was the first to admit, by setting his films mostly in his own known ambient, with personal friends in the cast and his own musical choice in the soundtrack, it is almost as if he was inviting us to make an analogy between the experience of real life and the stories that unfold on the screen. Appearing himself in several films 
playing characters with preoccupations similar to his can cause, agrees Woody, to double the intensity of such confusion. (Fox, 8)

But the Allen's film that best discusses the continuum between autobiography and fiction is Deconstructing Harry (1997), which was considered by numerous reviewers as autobiographical (although Allen has denied it) while other critics see in it a veiled portrayal of Philip Roth. It is certainly the most Roth-like of Allen's films; he never mentioned the name of Philip Roth in interviews, but a possible confirmation of such inspiration could be the fact that one of the characters in the film is played by Richard Benjamin, who also played the lead role in Goodbye Columbus, a film adaptation of a Philip Roth story. In any case, the film certainly evokes the theme of parasitism of art upon life best dramatized by Philip Roth in books such as Zuckerman Unbound or The Counterlife.

In the film, Allen plays Harry Block, a writer who uses facts from his personal life or from the private lives of relatives to construct his fictional stories. Harry is a good writer and he does good works-that, however, have the side effect of causing pain to other people. His exwife attacks him: "You take other people's suffering and transform it in gold-literary gold!" (Deconstructing Harry)

It is almost the same reproach that a character in a Philip Roth novel could present to Nathan Zuckerman. In Zuckerman Unbound, for instance, the fictional writer is disowned by his family for having written Carnovsky, that seems to describe their private lives in veiled form. When Nathan's father dies, his brother, Henry, accuses him of irresponsibility:

You killed him, Nathan. No one will come and say it to you. They are too scared to do it. They think you're too famous to be criticized-beyond the reach of ordinary human beings. But you killed him, Nathan. With that book. Of course he called you "bastard". He knew! He saw what you did to him 
and mum in that book! (...) You don't believe that what you write about people has real consequences. For you this is funny too - your readers will die laughing when they read about it. But dad did not die laughing. (Zuckerman Unbound, 274-275)

Another way in which Deconstructing Harry mirrors Roth's work is in its particular structure: as The Counterlife, the film is divided in several segments, parts which are short stories written by Harry, and parts which are the equivalent "reality" from which the writer took his inspiration. However, in Deconstructing Harry there is a more clear-cut separation between "reality" and "fiction", that are presented with different styles: the "real life" scenes are shot in a nervous way, edited with several jump cuts while the "fictional" sequences are filmed in long shots and with more conventional editing. This decision was conscious and befitting , explains Allen (Bahiana, 73): his idea was to show that, in life, the character Harry does not "function" properly, whereas in his "fiction" everything seems perfect and smooth. And this is why, in the end, Harry finishes giving a speech to his own fictional characters, thanking them for the success that he has achieved in his art, despite the many failures in his own personal life.

\section{Fiction and History}

Another common metafictional device is the use of non-fictional texts or images in the construction of a story. Historical or journalistic texts, documentary images, interviews (real or invented) with real living persons-all can be used and distorted in the context of a postmodern narrative. Such is the case of Woody Allen's Zelig and Philip Roth's Operation Shylock.

Allen's Zelig portrays New York in the twenties and thirties, showing the story of Leonard Zelig (played by the director), who is a sort of human chameleon, adapting to the shape and habits of the person or persons with whom he has had contact. He is, as someone describes 
him in the film, the "ultimate conformist." However, instead of following a conventional dramatization of events, the film is shot in black and white in a documentary-like style, frequently using actual material from newsreels of the twenties and thirties. The "fake documentary" part is filmed in exactly the same way in which the material would be shot at that time, thus making it difficult to separate real footage from studio-produced images: "We got old lenses from the 1920 's, old cameras and old sound equipment. We filmed it in exactly the kind of lighting they would have had at the time We made flickermattes, so that our films would have flickering light like the old films" (Woody Allen on Woody Allen, 137). Not only that, but also the actors were directed in a way that helped to reinforce the realistic approach:

Sometimes we'd shoot a scene and an actor would be crossing and the cameraman would say, 'Oh no, not yet! Come back!' And the actor wouldn't know what was hapenning and he'd go back. But it looked great on the screen. Because the actor was really caught and confused for a moment. We never warned anybody about anything. And we used amateurs for the speaking roles almost all the time. So you get a very realistic feeling. (Woody Allen on Woody Allen, 137)

To complicate things further, Woody's character is eventually made to appear superimposed on actual newsreel footage, positioned between real historical figures. Such "documentary" format is complemented by a series of contemporary interviews (obviously scripted) with real personalities, among them Susan Sontag and Saul Bellow. This is the only part of the film shot in colour, thus separating it from the newsreel part and at the same time reinforcing the idea that these interviews are contemporary reflections on "actual" archive images of the story of the main character, Leonard Zelig. Of course, we are aware that Woody Allen is just an actor, that such events never happened and that what we are seeing is a fictional creation using real-life material. But we are also made to question the common perception of documentaries as 
"truth", instead of thinking of them as just a different form of interpretation of reality.

In Roth's Operation Shylock, fiction and reality are also blended both in content and form. First of all, Roth ambiguously subtitles his book "A Confession." Then, in the Preface-a section normally left to non-fiction accounts or explanations-he says:

I've drawn Operation Shylock from notebook journals. The book is as accurate an account as I am able to give of actual occurrences that I lived through during my middle fifties and that culminated, early in 1988, in my agreeing to undertake an intelligence-gathering operation for Israel's foreign intelligence service, the Mossad. (Operation Shylock, 13)

Throughout the story he gives the narrator-character his own name, "Philip Roth" — and the story concerns his meeting in Israel with another character that has the same name as he has. The novel begins:

I learned about the other Philip Roth in January 1988, a few days after the New Year, when my cousin Apter telephoned me in New York to say that Israeli radio had reported that I was in Jerusalem attending the trial of John Demjanjuk, the man alleged to be Ivan the Terrible of Treblinka. Apter told me that the Demjanjuk trial was being broadcast, in its entirety, every day, on radio and TV. According to his landlady, I had momentarily appeared on the TV screen the day before, identified by the commentator as one of the courtroom spectators, and then this very morning he had himself heard the corroborating news item on the radio. Apter was calling to check on my whereabouts because he had understood from my last letter that I wasn't to be in Jerusalem until the end of the month, when I planned to interview the novelist Aharon 
Appelfeld. He told his landlady that if I were in Jerusalem I would already have contacted him, which was indeed the case-during the four visits I had made while I was working up the Israel sections of "The Counterlife", I'd routinely taken Apter to lunch a day or two after my arrival. (Operation Shylock, 15)

As the novel unfolds, historical facts and real texts-Roth's interview with Aharon Applefeld, the transcript of the judgement of John Demjanjuk in Israel, allegedly a Nazi camp guard known as Ivan the Terrible-merge with the fictional narrative. The story itself, of course, is a reflection on identity and its main characters are "Philip Roth" (the author) and a second "Philip Roth", or rather a man, also known as Moishe Pipik, who has usurped Roth's identity and is in Israel pretending to be him while promoting a political movement called Diasporism, which asks for the return of the Jews from Israel to Europe. Not content with that, Roth repeats (mirrors) the theme of the "double" in the exploration of an actual event, also central to the novel: the aforementioned trial of John Demjanjuk who might or might not be Ivan the Terrible. Therefore, we have a doppelgänger story, but one that, as Elaine Safer argues, is constantly calling our attention to its own construction, and in fact does not concern only two different personalities (Roth and his double), but three:

On one level, there are the shifting realities of Philip Roth, the fictional author, Pipik, the shadow self or the other, and the real author Roth. All three represent a quest central to the novel: how does one define the Jewish self? On a broader level, another question raised is how does one define the shifting nature of the existential self, a self that can possibly be a brutal torturer in a prison camp and later be celebrated as a paragon of virtue in a civilized suburban community. Does Demjanjuk represent the "horror the horror" of Conrad's 
Kurtz, who is a respected citizen in England and later a ruthless dictator in the jungle community where his power is the law, a man whose house is surrounded by a fence lined with human skulls? Even this glimpse of the heart of darkness is mingled with farce for Roth as realistic particulars of the trial (not over at the time of Roth's writing) are merged with farcical antics of the protagonist and his double. (Safer, 7)

The plot at some points becomes so absurd that few people would really think that the story of Roth's double has anything to do with real events-even in the preface, Roth's assessment that he has agreed to undertake an operation for Israel's Mossad seems highly suspicious. But the fact is that the real events that are merged within the fictional narrative-specially Roth's witnessing of the trial of Demjanjunk/Ivan the Terrible but also of the ongoing Arab-Israeli conflict-are not so easily dispelled as "mere fiction". And the fact is that it is not only until the very end, in a final note to the reader, that Philip Roth finally concedes that his book is not based on a real personal experience: "This book is a work of fiction. This confession is false." (Operation Shylock, 399)

Both Zelig and Operation Shylock, perhaps exactly because of their "documentary" and "confessional" format, with the use of real images or texts integrated in a fictional context, end up discussing real historical events. If Operation Shylock, beyond a story about personal identity and doppelgangers, is also a very serious reflection on Israel, Nazism and the Arab-Israeli conflict, curiously enough Zelig (other than a similar reflection on identity) is in its own way one of Allen's most overtly political works. In one of the interviews inside the film, Saul Bellow says that "Something in him desired merging into the mass and anonimity-and fascism offered Zelig this opportunity" (Zelig). The film is, indeed, a reflection on how conformism, or the will to accept and live by other people's norms, might lead to a totalitarian regime. 


\section{Closure}

Film and literature are different art forms in their instruments and their effects, and a thematic comparison of the work of Woody Allen and Philip Roth is bound to show that they do have more differences than one would suppose. Even their common use of metafictional devices, their constant intertextual references, their almost narcissistic self-reflexivity (less kind critics would call it self-obsession) are used in different ways and with different purposes. For Woody Allen, there is clearly an opposition between a "reality", represented as the mundane and sad events of daily life, and its artistic reconstruction, where the absurd nature of the world gains an organized form-providing, perhaps, a trite consolation both to spectator and artist. For Philip Roth, no such clear-cut divisions seem to exist: for him, it is impossible to represent "reality" other than as a kind of construct, more or less based on facts, and even autobiography could be shown to be "probably the most manipulative of all literary forms" (Roth qtd. in Finney, 3). Paradoxically, Roth's view of art and artists seems to be less ambiguous or disenchanted than Allen's. Zuckerman's (and Roth's) recurrent use of factual events in fiction seems less a pathetic attempt to give meaning to their disorderly private lives or to dispell their anxieties than a sort of uncontrolled artistic impulse, a deep conviction that only through fiction reality can be exposed or represented, and perhaps at least partially comprehended. After all, "The problem is not that everything should become a book. It's that everything could become a book. And it does not count as life until it becomes." (Zuckerman Bound , 157)

\section{References}

Allen, Woody. Complete Prose. New York: Simon and Schuster, 1990.

Allen, Woody and Björkman, Stig (Ed.) Woody Allen on Woody Allen. In conversation with Stig Bjorkman. London: Faber and Faber, 1993. 
Alvarez, Al. "The long road home." Interview with Philip Roth. The Guardian Unlimited. Retrieved September 11, 2004, from http:/ / books.guardian.co.uk/review/story/ 0,1300982,00.html.

Annie Hall. Dir. Woody Allen. Writ. Woody Allen and Marshall Brickman. Perf. Woody Allen, Diane Keaton. United Artists, 1977, 93 min.

Bahiana, Ana Maria. "O Espelho Desconstruído". Interview with Woody Allen. In: Bravo! 5, February 1998. 72- 78.

Bailey, Peter J. The Reluctant Film Art of Woody Allen. Lexington: Kentucky University Press, 2001.

Bullets Over Broadway. Dir. Woody Allen. Writ. Woody Allen and Douglas McGrath. Perf. John Cusack, Diane West. Orion, 1994, 119 min.

Deconstructing Harry. Dir. Woody Allen. Perf. Woody Allen, Elizabeth Shue, Judy Davis. Sweetland, 1998, 96 min.

Finney, Brian. "Roth's Counterlife: Destabilizing The Facts". 1993. California State University Long Beach site. Retrieved February 10, 2005, from http:// www.csulb.edu/ bhfinney/ Roth.html.

Fox, Julian. Woody: Movies from Manhattan. Julian Fox. Woodstock, N.Y.: Overlook Press, 1996.

Halio, Jay L. Philip Roth Revisited. New York: Twayne, 1992.

Husbands and Wives. Dir. Woody Allen. Perf. Woody Allen, Juliette Lewys, Judy Davis, Sydney Pollack. TriStar,1992, $108 \mathrm{~min}$.

Play It Again, Sam. Dir. Herb Ross. Script: Woody Allen, based on his play. Perf. Woody Allen, Diane Keaton. Paramount, 1972, 85 min.

The Purple Rose of Cairo. Dir. Woody Allen. Perf. Jeff Daniels, Mia Farrow. Orion, 1986, 119 min. Roth, Philip. The Counterlife. New York: Farrar, Straus and Giroux, 1986.

Roth, Philip. Operation Shylock: A Confession. New York: Simon and Schuster, 1993. 
. Portnoy's Complaint. New York: Random House, 1969.

. Zuckerman Bound: A Trilogy and Epilogue. (The Ghost Writer, Zuckerman Unbound, The Anatomy Lesson and The Prague Orgy). New York: Farrar, Straus and Giroux, 1985.

_. Zuckerman Unbound. New York: Farrar, Straus and Giroux, 1981.

Safer, Elaine B. "The double, comic irony, and postmodernism in Philip Roth's Operation Shylock". MELUS, v. 21 (Winter 1996): 157- 72.

Zelig. Dir. Woody Allen. Perf. Woody Allen, Mia Farrow. Orion, 1983, 79 min. 